\title{
TRACKING THE EMPLOYMENT RELATIONS LAW REFORM BILL
}

\author{
Janet Bedggood \\ School of Communication Studies \\ Auckland University of Technology
}

\begin{abstract}
This paper analyses the media coverage of the Employment Relations Law Reform Bill in the New Zealand Herald and the National Business Review which followed the Bill's passage into law. It considers the media as a 'site of struggle' through their publication of the attempts to influence the Government to change or retain measures, from contending perspectives of both businesses and trade union leaders. Their different views were strongly expressed in the initial reporting in the 'Working to Rules' series in the Business Herald which examined the new provisions for bargaining in the bill. The reports of the submissions to the Select Committee also covered diverse views from the community.
\end{abstract}

The paper assesses the Government response to these viewpoints in terms of the modifications to the original Bill and compares the requirements for bargaining in the new law to those in the Employment Contracts Act 1991 (see Harbridge, 1993) with those in the Employment Relations Act (see Boxall,2001, Wilson 2001).

\section{The Broader Context of Employment Law}

Labour law has developed in New Zealand in response to both economic conditions and political demands on parties to represent the interests of workers and/or employers. Labour relations were a central aspect of the Welfare State, beginning in the 1890 s with the Industrial Conciliation and Arbitration Act 1894 which established a state role in balancing the interests of employers and employees and mediating between them. This was intended to minimise disruption at work. The state's role was invariably under challenge in periods of economic downturn when the ability of employers to make concessions to workers was limited'.

These occasional tendencies intensified from the mid seventies when New Zealand's economic decline and deteriorating conditions for capital accumulation put pressure on the ability of the state to sustain conditions of the Welfare State. According to Boxall (2001) these conditions changed the climate of industrial relations and bargaining became more direct and less formal after the abolition of compulsory arbitration in 1984. The state role enshrined in the Industrial Conciliation and Arbitration Act was undermined and came to be seen as an impediment to the operation of a free market by employers. The solution was to further restrict the state role and remove legal protections of workers rights. The Employment Contracts Act (ECA) sought to provide the framework for this to occur in the name of flexibility for owners/employers. Unions are not mentioned in the Act. It took away the traditional legal rights for union organisation through establishing an individual contract system, removing unions from monopoly coverage, making union membership voluntary and removing award blanket coverage (Harbridge, 1993).

Although the fourth Labour Government had begun the project of dismantling and privatising much of the state sector, they had been reluctant to deregulate industrial relations. The new National Government were not so timid. The political justifications at the time have a resonance with the debates over the Employment Relations Law Reform Bill. Prime Minister Jim Bolger made it clear that deregulation of the labour market was a central plank for restoring profitability. He blamed the trade unions for the state of the economy. As Jeff Gamlin said later "National declared war on the union movement in 1991". (Gamlin, 2003)

The Act was an employers' act. Cabinet papers revealed that the policy was formulated within Government in association with "powerful business groups" and without the customary consultation with other sectoral groups affected by the legislation such as the New Zealand Council of Trade Unions (CTU) (Walsh and Ryan, 1993). The CTU complaints in 1991 paralleled those from business groups in 2004 who claimed that the Government had consulted only unions over the Employment Relations Law Amendment Bill. and business lobby groups were not involved (see Eagles, 2004c). Further, when the Business Roundtable (BR) used the Official Information Act to obtain a CTU submission to Government advocating employment law reform, they uncovered the source of the bill. According to Norman LaRocque of the BR "the broad objectives and policy direction of the union submission and the new bill are remarkably similar [and]in key cases the drafting is actually identical" (LaRocque, 2004,). Of the 53 CTU requests, only 2 were rejected outright by Government.

The BR input into the ECA was public knowledge from when the BR campaigned to convince the government and the business community to radically change employment law. They agitated for the removal of the provisions in the Labour Relations Act 1987 retaining trade union monopoly of bargaining rights and blanket coverage for awards because they saw as impediments to a flexible labour market (Walsh and Ryan,1993). Their policy points became part of National Party election 
policy in both 1987 and 1990. The 1990 National party election manifesto claimed that labour market flexibility would enable New Zealand to join the 'powerhouse economies of the world" and deliver "true democracy in the workplace". They persuaded another powerful business group, the Employers Federation, to support the policy.

The provisions on bargaining and representation were central to the ECA and clearly reveal the endorsement of BR policy by Government politicians and by Treasury. However, the Government did not accept every aspect of the BR and Treasury proposals. The proposal to remove specialist legal institutions was not implemented by the Government. According to Walsh and Ryan (1993) mechanisms for dispute resolution and minimum codes of employment remained under specialist jurisdiction because of the practical difficulties in integrating these measures into the mainstream court system ${ }^{2}$.

The same 'big business' capitalist interests who promoted the Employment Contracts Act, opposed its repeal and the introduction of the Employment Relations Bill (ERB) in 1999. In the months before the passing of the Employment Relations Act, the business lobbyists went on a sustained offensive against the Bill.

At the same time, unions were campaigning for the Bill under the slogan 'Fairness at Work' following the Minister of Labour, Margaret Wilson's line that the Bill sought to balance the rights of employers to run their businesses and the rights of workers to be treated fairly (Wilson, 2001). Wilson argued the labour market reform was in line with the Labour Government's policy for economic management rather than a free market. She wanted the notion of the employment relationship as an economic contract to be replaced with that of a relationship of mutual trust. This was to be achieved through good faith in employment relationships. The objects section of the Act recognised the "inherent inequality of bargaining power in employment relationships". Unions would be strengthened so they could overcome their position of weakness and 'good faith' would create co-operation between employers and workers. Unions would grow through promoting collective agreements (only unions could bargain for workers and negotiate collective agreements) by allowing for multi-employer bargaining and by giving unions a greater role in the workplace through right of entry.

The provisions retained from the ECA were strike laws, individual contracts and redress through the legal means of the personal grievance system through a new statutory body, the Employment Relations Authority which would decide if 'unfair' bargaining had occurred (Boxall 2001, Wilson 2001).

These measures were attacked by the business community who supported the ECA and accused the Government of being 'arrogantly anti-business'. Two leading examples were first, the head of the Employers Federation, Steve Marshall, who warned that the law would lead to high unemployment (Fallow, 1999) and second, Max Bradford, the Opposition Shadow Minister of Labour, who claimed it would discourage investment, cause 'disruption', cost jobs and lead to compulsory unionism (Small, 2000). The alarmist rhetoric appeared to have a direct effect on business confidence. By June the National Bank business confidence survey showed the most dramatic drop in business confidence since the survey began, despite economic indicators of a buoyant economy with high exports, and high export prices and a reduction in unemployment. The Government and the CTU president Ross Wilson played a conciliatory role in reassuring business and the Bill was modified to meet business concerns.

In the debates over ERLRB, the term 'winter of discontent' was used frequently not only to refer to the opposition to the ERB in the winter of 2000 but also to suggest another 'winter of discontent' was occurring. Once more business organisations and prominent business leaders were on the offensive against the Government's employment law. Trade unions were fearful that yet again, Government would modify the bill in response.

The Employment Relations Law Reform Bill (ERLRB) changed the ERA to redress the weaknesses still existing for unions and lack of union density. To improve conditions for unions the Bill made the following changes:

- Promote collective bargaining and multiemployer collective agreements (mecas) - if they are sought employers must attend at least one meeting

- Vulnerable workers jobs and conditions protected when businesses are sold or contracted out

- Good faith provisions strengthened with fines up to $\$ 10,000$ for "serious and sustained breaches"

- A breach of good faith if employers pass unionnegotiated wages and conditions to non-union ('free riding') workers

- Personal grievance and dismissal provisions strengthened

- the Employment Relations Authority will impose solutions, even collective agreements, if negotiating parties reach an impasse

\section{Media coverage of Employment Relations Law Reform Bill}

The media coverage of the Bill in the New Zealand Herald and the National Business Review will be considered in four ways. First, I will look at the articles reflecting the interests of business organisations and leaders, second, the articles from union points of view, third, the reports of Select Committee (SC) submissions and four, the reports of the SC's recommendations. Finally, I will assess the SC report as a measure of the Government response to competing views and the 
possible influence of the media in acting as a forum for these views to be contested.

\section{Business views in the media: a return to old laws?}

The New Zealand Herald, NZ's biggest circulation newspaper, editorialised strongly against the Bill. The Business section ran a 'Working to Rules' series on workplace reform in January to comment on the bill. Of the 10 stories in the series, some warned of the problems for businesses in the United States. The headlines of the $\mathrm{NZ}$ stories reflect what the Herald later called 'the mood of the boardroom'; "Employers set for stoush on job law reform", "Bosses; More rights, less work", "Perils of protection law", "Twin hurdles on road to reform", "Recipe for ruin". The coverage prompted one unionist to comment that "the Herald has done the real job of political opposition to the Bill" (Jackson, 2004).

These stories and others show that many employers were nervous that some measures marked a surreptitious return to introducng pre-ECA measures, despite assurances from Margaret Wilson (James, 2003) that there will be no return to compulsory unionism, compulsory arbitration or national awards.

In the first Working to Rules story "Employers set for stoush on job law reform" Jim Eagles, the business editor, and Paula Oliver reported on 3 surveys that were conducted to canvass small, medium and large businesses on their reactions to the Bill (Eagles and Oliver, 2004). The respondents were "overwhelmingly opposed" to the Bill. The Auckland Chamber of Commerce surveyed small and medium businesses, Business NZ/KMPG did a compliance costs survey which found the responses were very negative except for workplace safety. The Business Herald's Business Leaders survey canvassed 50 senior business leaders who responded angrily that 'overregulation' of industrial relations would have a negative effect on business. Some business leaders commented negatively on particular measures. For them, the most unpopular aspect of the changes was strengthening the provisions for mecas. They saw that dealing with larger groups of organised workers across several work sites, posed a threat to their interests. They felt it might be a move to re-establish national awards.

Other stories on mecas took the same position. In an earlier opinion piece by Rob Towner, a lawyer from the legal firm Bell Gully, Towner saw mecas as a return to centralised bargaining (Towner, 2003). The Herald headline "CTU pushes for a return to old awards' (Eagles, 2004d) ran above the claim that "multi-employer contracts seen as a stepping stone to national awards". Roger Kerr of BR warned that multi employer contracts would create class warfare (Kerr, 2004).

Other objectionable measures were the transfer of businesses provisions and personal grievances provisions. These problem areas were investigated in subsequent stories in the series.
In 'Bosses;More rights, less work' Eagles focused on personal grievances and grounds for dismissal which the business surveys showed were among the most unpopular parts of the Bill for employers (Eagles, 2004a). Some said that the additional costs and regulations would dissuade them from employing new staff. Eagles reported Ross Wilson of the CTU as saying the test for justified dismissal had moved back to the beginning of the $1990 \mathrm{~s}$, a statement likely to exacerbate the fears of a return to employment law before the ECA.

A Herald editorial was critical of the justification for dismissal in the Bill giving the courts jurisdiction over "whether the employer's decision was reasonable and fair in the circumstances".(Herald, 2004). The editor suggested the case won by the Herald in the Court of Appeal $^{3}$ was the reason for extending the requirements for dismissal. Herald editorial staff objected to this selfserving line of argument (see below).

Employers also objected to the transfer of business provisions where existing staff are kept on when a business changes. Employers persuaded the Government to remove a similar provision from the Employment Relations Bill. In 'Perils of the protection law' (Eagles, 2004b) Spotless Services complained about compliance costs and the dangers of disclosing commercially sensitive information. In other stories these concerns were reiterated. One cleaning contractor (Eagles, 2004c) claimed the proposal was unworkable on several counts. The new contractor might have "good reasons" for not wanting to employ staff and the client may have changed the contractor because of staff behaviour. The transfer of provisions would restrict profitability.

"Recipe for ruin' (Eagles, 2004c) covered a range of complaints about the bill, based on interviews with leading business men, Simon Carlaw of Business New Zealand, Michael Barnett of the Auckland Chamber of Commerce, Roger Kerr of NZBR and Peter Tritt of the Employers and Manufacturers Association. Kerr referred to the depth of concern in the business community inferring that the leaders were representing these views. Carlaw suggested the bill would not help economic growth. They all called on the government to abandon the bill.

Carlaw complained that the imposed remedy for breaching good faith was too draconian. It would mean a loss of freedom for bosses and signalled a return to compulsory arbitration.

Another theme of coverage was encapsulated in headline of a Herald story published when the bill was introduced into Parliament 'Unions to get more power' (Taylor, 2003) Two stories in the NBR explored the problems of legal solutions for strengthening unions. In 'Courts to' keep unions alive' Jeff Gamlin argued the bill was a futile attempt to bolster unions with legal protections when they lack industrial muscle (Gamlin, 2003). It moved employment issues from the picket lines to the courts. In the same issue Alex Sundakov made a classic free market argument linking decline of unions to a more open competitive economy where "market disciplines and 
competitive pressures" shape wage rates and conditions for workers rather than unions (Sundakov, 2003).

Margaret Wilson was well aware of the problems of union weakness. She attributed the 'relative ease' of the passage of the ECA to the industrial relations framework created by the Industrial Conciliation and Arbitration Act where unions historically relied on state support rather than their own industrial muscle (Wilson, 1994: 267). Her mission to strengthen unions involved giving them statutory support to reverse the fragmentation of the labour market and provide a framework to overcome casualisation, deskilling and low productivity (Wilson, 2001:7).

Some of the attacks on the bill targeted her as the key architect of the changes. Eagles and Oliver refer to one chief executive saying "mad-hatter Margaret clearly has a collectivist-socialist pathology and a deep hatred of business" (Eagles and Oliver, 2004). Later Eagles concluded "the business community sees Wilson as a dangerous zealot driven by an anti-capitalist ideology" (Eagles, 2004c). The NBR saw her as out of touch with the electorate, pushing through policies by a "political style of stealth and arrogance" (Bryant, 2004). By the time Fran O'Sullivan declared it was "clear she had become a political liability" she had already stood down as Minister of Labour (O'Sullivan, 2004).

Wilson' replacement, Paul Swain was seen as more business friendly (Chapple and Taylor, 2004) and media speculated that the change indicated that Government was succumbing to pressure from business. John Tamihere fostered this impression when he hinted at a diluted Bill (Hopkins 26/3/04) In an interview he admitted the bill was "hugely unpopular' and he wanted to make business friendly changes like subsidies for small business tax. He said the bad press for MW was tough and "we'll see what Sivainey and the boys can get up to now the girl's out of the way for a while". In the next day's Herald Tamihere was quoted saying "yanking the ERLRB might not be able to be done, but mitigating the worst excesses of it may well be" (Fallow, 2004).

In another NBR column headed 'Swain needs to throw out Madge's goodies' Peter Tritt gave advice to Swain to reconsider the bill (Tritt, 2004a). The NBR was following the line that a change in Labour Minister signalled changes in Bill beneficial to business.

By September Tritt was less optimistic over Tamihere's role (Tritt, 2004b). He observed that Tamihere in presenting himself as supporter of small businesses took a report from the Small Business Advisory Group and used the issue of dismissal procedures to undermine the big business lobbies of EMA and BusinessNZ. Tritt had no confidence he would be effective in convincing Cabinet to support business concerns.

\section{Alternative views from business}

Although the Herald series had emphasised the "unprecedented anger" of employers responses to the Bill (Eagles, 2004c) the Government may have seen this as an exaggeration because of some other statements from businessmen. Even in the first reports of the business surveys showing opposition to the Bill, one business leader was reported as saying that the negative reaction was alarmist and the Bill was in line with worker protections in OECD countries.

In December, a Herald story reporting a range of reaction to the Bill, quoted Ralph Waters the Chief Executive (CE) of Fletcher Building as saying that the changes were not dramatic; "I'm all for doing good things for those who work and earn a modest living" (Oliver, 2003).. In a March story on 'Return of the Roundtable' Waters raised issues with the way the BR "villified" some CEs for challenging the business lobby's line. (O'Sullivan, 2004).

The members of the Government business thinktank, the Business Council for Sustainability also supported the Bill.

Admissions that ERA was acceptable to business undermined many of the criticisms of the new Bill. Significantly, Roger Kerr (2004) said that ERA remained "enterprise focused" after the "worst features of the Bill were watered down". By September even the Opposition leader Don Brash admitted in the House that "business community broadly happy with ERA" (Taylor, 2004c). In April NBR carried a poll, emphasised the results which showed marginal opposition to the ERA since June 2001 (Smith, 2004a). But a more important finding was strong disapproval of ECA and popular support for the ERA, despite the disquiet from business community.

In February Treasury advised that the law changes would have "modest" impact (Oliver, 2004a).

The Prime Minister Helen Clark revealed her reaction to the complaints in January $21 / 1 / 04$ by telling business to "calm down", referring to their "silly rhetoric" (Taylor, 2004a).

\section{Unionists view}

A day after the content of the Bill was announced, Herald columnist John Armstrong assessed what the measures would deliver to employers and employees and their likely reactions to it. He predicted a "chorus of doom from the entrepreneurial classes" in a Bill that he thought made only "minor concessions to unions". Armstrong remembered the reaction to the ERA when it was introduced in 2000. He concluded that the Bill provided for only "modest changes to a modest law" because the Government was cautious after that "winter of discontent" (Armstrong, 2003).

This opinion piece was exceptional Herald coverage by their own reporters for taking a sceptical view of the reaction from the business lobby. It ran counter to editorial policy on the Bill

Armstrong's sentiments were shared by the proponents of the Bill. Margaret Wilson, Minister of Labour and Ross Wilson, President of CTU both agreed the "bosses will complain", Margaret Wilson (2004) calling them "spinners of doom" and Ross Wilson (2004) referring to 
their "overblown" objection to ERA in 2000. Ross Wilson referred to hysterical employers when it is just a "modest law to underpin a modern economy (Ross Wilson, 2004). The CTU secretary Carol Beaumont (2004) saw the Herald itself as "promoting business panic" with antiworker rhetoric in stories.

Later in January the $N B R$ carried a story that never appeared in the Herald (Smith, 2004b). Herald journalists objected to the editorial on grounds for dismissal in the Bill (see above). They wrote to management declaring the Herald should have disclosed a conflict of interest when printing the editorial, because of their own breaches of good faith bargaining ${ }^{4}$. The staff were supported by their union who also thought paper should have disclosed its own industrial relations problems, calling the editorial a "thinly disguised piece of industrial sabotage".

The Herald defended itself by pointing to "articles offering dissenting views on Employment law". It ran four articles by trade unionists and one from Margaret Wilson endorsing the bill. This number matched the five it published written by opponents to the bill. NBR ran no articles in support of the bill.

\section{Trade unions response conciliatory}

If employers spoke (almost) in unison, so did worker representatives. After predicting that businesses would complain and generate panic like they did over the original ERA, trade unionists reacted to the complaints using the same line of argument. They attempted to persuade business that it would be in their interests to support the bill.

Margaret Wilson (2004) promoted her Bill by emphasising that workers and bosses have interests in common and that good profit and improved working conditions go together, She tried to persuade bosses that the bill would benefit business because improved working conditions for workers would be good for business.

The appeal to the good business sense of the bosses was echoed by Bill Andersen. In a piece headlined 'Only bad bosses need fear law change', he claimed that if a business was run on a sound investment plan, was informed by market research and had good labour relations, the new law would be great for them (Andersen, 2004). In a letter to Herald Beaumont also emphasised that "good employers will not be concerned about this bill" (Beaumont, 2004)

On a wider economic level the CTU economist, Peter Conway explained the bill as part of policy that would "lift productivity and growth" (Conway, 2004). Ross Wilson claimed that unions would "work with businesses to manage the economy by helping plan and organise work, to increase productivity and develop economic strategies"(Wilson, 2004).

Although the Bill referred to the "inherent inequality of power' in the workplace, that was not acknowledged by the unionists in their conciliatory approach in the debates.
These arguments seemed designed to convince Government rather than business, that unions know more about business and the economy than businesses.

\section{Reports of Select Committee hearings}

The Transport and Industrial Relations Select Committee received 354 submissions from employers, business lobby groups, trade unions, community groups, lawyers and individuals on the bill. Most (approximately 60\%) were from employers and the business lobbyists (Parliamentary Library, 2004).

When the Select Committee sat, the Herald reported on a handful of oral submissions and the NBR only two. Two of the stories covered union submissions, one was from the legal profession and six from businesses and employer lobby groups. This balance matched the balance of submissions.

From its first stories on the Bill, the Herald focussed on freeloading as a major concern for ordinary unionists [Dearnaley and Tayor, 2003). This issue was headlined in the report of the CTU submission 'CTU proposals aim to block free-riding' (Oliver, 2004c). Yet Ross Wilson presented 39 pages of alterations to the bill seeking compliance with ILO conventions. As well as strengthening the clause making it a breach of good faith to pass on the terms of the collective to individuals, Wilson argued for promoting more multi-employer bargaining and widening the right to strike.

The other story covering a union submission was the first story on submissions which presented "two widely opposing views", one from Business New Zealand and one from the bank workers union, Finsec (Oliver, 2004b). Finsec objected to the way banks passed on the terms of collective Agreements to staff on individual contracts. This was reiterated in another story when Westpac admitted they did this (Oliver, 2004e).

For Business New Zealand Carlaw argued that the bill "signalled a return to compulsory bargaining, compulsory arbitration and national awards"(Oliver, 2004b). He saw the meaning of the 'good faith' provisions as impenetrable. This point was taken up in the judges' submission that the precise meaning of this part of the law was unclear (Oliver, 2004d).

Many companies pointed out the compliance costs would make it difficult for them to run their businesses. John Bongard, Managing Director of Fisher and Paykel hinted that his international company might not "stay here" (Chapple, 2004a) Both Spotless Services and Realtors saw the transfer of undertakings so unworkable it would effect the viability of their businesses (Chapple, 2004b, $N B R$, 2004). The supermarket company Foodstuffs objected to union access to worksites, which disrupted their business operations (Chapple, 2004c).

Both papers carried stories on employers' objections to the 'indecent speed' required for submissions and their threats to boycott the process (Dearnaley, 2003, Lill, 2004) There were no boycotts but one unusual incident. 
$N B R$ reported EMA members expressing both their anger and restraint. They met at Alexandra Park two floors below SC hearing where they resolved to reject the bill. Then over 200 from the protest meeting went upstairs and "filed quietly" into the hearings. When EMA chief Alisdair Thompson read their resolution, they applauded and "the crowd then left, as quietly and as orderly as it had arrived"(Tritt, 2004d).

\section{Coverage of Select Committee Report}

Although the SC listed twelve key measures they had considered and modified (Transport and Industrial Relations Committee, 2004:1-2) the improvements for unions at the centre of the Bill remained substantially intact. The media reported on some of the changes, highlighting legalising bargaining fee arrangements and dropping the requirement for employers to attend the first meeting of a meca (see Taylor, 2004b, Mills and Hill, 2004). The Bill clarified the definition of good faith and raised some thresholds. Employers breach good faith if they "do anything" to induce employees not to join a collective; any breach must be deliberate and employers do not have to disclose confidential commercial information. Collective bargaining is linked to a collective agreement. The Bill alters the test for justification of dismissal.

The responses from the sectoral groups were muted. $N B R$ claimed that the 17/9/04 Select Committee of 'former union officials" had failed to redress employer concerns. The Herald reported that although the SC removed the cmployers main objection, the compulsion to attend a meca meeting. Business NZ saw it as a "bad law marginally improved" (Taylor, 2004b). The CTU saw the restriction on mecas as a "big setback" although the introduction of a bargaining fee was welcomed and on balance the bill was "OK". Ross Wilson added that he expected wide support for the changes after "extensive consultation with the CTU and Business NZ".

Rod Oram claborated on the consultation in the Sunday. Siar Times (Oram 2004). Business NZ head Simon Carlaw and Ross Wilson, president of the CTU had a "series of meetings, to find common ground" on the contentious provisions. They reported back to the SC on ten they had reached agreement on and five appeared in the amended bill. The comments from business appeared to be a ritual stand-off after this consultation.

Neither the Herald nor the NBR reported on the second reading of the Bill in Parliament on October $5^{\text {th }}$.

\section{Conclusion}

The political dimension in the media treatment of the Bill emerged as a significant factor of coverage. The intensity of the early reporting and comment on the Bill is in sharp contrast with the intermittent coverage once the Select Committec hearings began. The limited number of stories in both papers covering the Select Committee hearings and the Parliamentary debates on its reintroduction into the House, suggests diminishing interest in the Bill. This in turn suggests that the early coverage was calculated to effect the Bill itself and once this seemed unlikely, reporting tapered off. I have suggested that there were indications that the Government was not going to succumb to pressure from business lobbyists, particularly when Helen Clark admonished them in January.

The papers' editorial positions supported the business lobbies' campaign against the Bill. As well as editorials, many of the stories took a political line. Although the Herald allowed several trade unionists put their views, the unionists' positions were largely defensive and conciliatory reactions to the business case. The Herald was outed as a protagonist by its own staff for not declaring its own interests in its own employment dispute in its editorial. The Select Committee report referred specifically to the Bill seeking to overturn the decision in the Herald case (Select Committee Report, 2004, p15).

The momentum of the earlier coverage can be seen as part of the campaign against the Bill driven by the expectation that from those advocating for business interests, that they could persuade the Government to back down as they did in 2000 . The public opposition expressed in the media was instrumental in diluting the final form of the ERA.

In 2004, the struggle in the media was not the defining or decisive struggle over the Bill. Decisions over what to modify were made in Cabinet and in the Select Committee meetings away from public scrutiny. The final debates in Parliament are yet to occur but the outcome is likely to ratify decisions already made.

\section{References}

Anderson, G. (1996). Introduction. New Zealand Journal of Industrial Relations. Symposium: the specialist institutions: the Employment Court and the Employment Tribunal. 21, 1, 11-4.

Boxall, P. (2001). Evaluating Continuity and Change in the Employment Relations Act 2000. New Zealand Journal of Industrial Relations. 26, 1, 27-44

Harbridge, R. (1993) Bargaining and the Employment Contracts Act: an overview. In Harbridge R. Ed Employment Contracts: New Zealand Experiences. $31-52$.

Parliamentary Library. (2004) Submissions List for Employment Relations Law Reform Bill.

Transport and Industrial Relations Committee. (2004). Employment Relations Law Reform Bill.

Walsh P. and Ryan R. (1993) The Making of the Employment Contracts Act. In Harbridge R. Ed. Employment Contracts: New Zealand Experiences. 13-30.

Wilson M. (2001) The Employment Relations Act: a statutory framework for balance in the workplace. New Zealand Journal of Industrial Relations. 26, 1, 5-12. 
Wilson M. (1994). Labour in Government. 1984 - 1987. Wellington: Allen and Unwin.

Newspapers: National Business Review

Bryant, N. (2004). Wilson makes it her last stand. National Business Review, 19 March. 1.

Gamlin, J. (1993) Courts to keep unions alive. National Business Review, 12 December. 33.

Hopkins, B. (2004) Tamihere to cast fresh eye over Wilson's mess. National Business Review, 26 March. 8.

Lill, C. (2004). Employers boycott Committee deadline. National Business Review, 20 February. 4.

Mills, J. And Hill S. (2004) Understanding theproposed changes to employment bill. National Business Review, 24 September. 44.

National Business Review (2004) Realtors warn on ERL Bill. National Business Review, 4 June. 15.

Sundakov, A. (1993) ERA Amendments hurt trade unions. National Business Review, 12 December. 33.

Smith, N. (2004a) Labour law discontent rises. National Business Review, 8 April.16.

Smith, N. (2004b) Herald stance triggers union stoush. National Business Review, 30 January. 4.

Tritt, P. (2004a) Swain wants to throw out Madge's goodies. National Business Review, 26 March. 43.

Tritt, P. (2004b) Employment law poorly drafted. National Business Review, 17 September. 43.

Tritt, P. (2004c) Tamihere bags business as snowball rolls. National Business Review, 10 September. 42

Tritt, P. (2004d) Not mad as hell, but not going to take it any more. National Business Review, 7 May. 30.

New Zealand Herald

Andersen, B. (2004). Only bad bosses need fear law change. New Zealand Herald. 22 January. C2.

Armstrong, J. (2003) Playing it safe in the workplace. New Zealand Herald. 6 December.

Beaumont, C. (2004) Letters. New Zealand Herald. 28 January. C4

Conway, P. (2004) Sweeping away remains of contracts law. New Zealand Herald 3 February. C2.

Chapple, I. (2004a) F \& P losing patience with Govt. New Zealand Herald. 29 April. C3.

Chapple, I. (2004b) Contract law bill open to abuse. New Zealand Herald. 4 May. C3.
Chapple, I. (2004c) Foodstuffs 'attitude problem'. New Zealand Herald. 11-2 May. C4

Chapple, I and Taylor K. (2004) Swain immediate target for discontent. New Zealand Herald. 26 February. $\mathrm{Cl}$

Dearnaley M. (2003) Lobbyists threat to miss ERA deadline. New Zealand Herald. 17 December. A5.

Dearnaley M. and Taylor K. (2003) 'Freeloaders' in unionist's sights. New Zealand Herald. 14 December. A4.

Eagles J. And Oliver P. (2004) Employers set for stoush on job law reform. New Zealand Herald. 12 January. C1

Eagles, J. (2004a) Bosses: more rights, less work. New Zealand Herald. 14 January. $\mathrm{Cl}$

Eagles, J. (2004b) Perils of the protection law. New Zealand Herald. 15 January. $\mathrm{C} 1$

Eagles, J. (2004c) Recipe for ruin. New Zealand Herald. 17-18 January. $\mathrm{Cl}$,

Eagles, J. (2004d) CTU pushes for return to old awards. New Zealand Herald. 2 February. C1,

Fallow, B. (2004) Tamihere hints at diluted bill. New Zealand Herald. 27 March. C3.

Fallow, B. (1999) Labour jobs contract alarms employer spokesman. New Zealand Herald. 17 November.

Jackson, M, (2004). Letters. New Zealand Herald. 28 January. C4

James, C. (2003) 'Good faith at heart of employment reform bill. New Zealand Herald. 4 December.

Kerr, R. (2004) Employers see bill as death by a thousand cuts. New Zealand Herald. 22 January. C2.

La Roque, N. (2004) Scrap labour bill and start again. New Zealand Herald 3 February. $\mathrm{C} 1$.

New Zealand Herald. (2004) Job growth at risk from law changes. New Zealand Herald. 19 January, A12.

Oliver P. (2003) Experts shake heads over jobs relations bill. New Zealand Herald. 6 December.

Oliver P. (2004a) Business groups slam Treasury claims. New Zealand Herald. 27 February. C3

Oliver P. (2004b) Business, bank workers want changes to the bill. New Zealand Herald. 5 March. C3

Oliver P. (2004c) CTU proposals aim to block free riding. New Zealand Herald. 19 March. C3. 
Oliver P. (2004d) Judges say jobs law unclear. New Zealand Herald. 24 March. C3.

Oliver P. (2004e) Non-union workers receive union gains, admits Westpac. New Zealand Herald. 10=11 April. C3.

O'Sullivan, F. (2004) Return of the Roundtable. New Zealand Herald. 27 March. C1

Small, V. (2000) Employment law - good faith the key. New Zealand Herald. 15 March.

Taylor, K. (2003) Unions to get more power. New Zealand Herald. 5 December

Taylor, K. (2004a) PM tells business to calm down. New Zealand Herald.. 21 January. C3.

Taylor, K. (2004b) Union clear to bill 'freeloaders'. New Zealand Herald. 14 September. A5.

Taylor, K (2004c) Labour leaps on Brash. New Zealand Herald. 15 September. A6.

Towner, R. (2003) Grounds to worry over work bill. New Zealand Herald.9 December. C10.

Wilson, M. (2004) Drop the rhetoric and we'll forge a good law. New Zealand Herald. 23 January. C2.

Sunday Star Times

Oram, R. (2004) Lobbyist outrage doesn't fit the bill. Sunday Star Times. 19 September. D2.

Wilson R. (2004) Moving to a modern economy. Sunday Star Times. 15 January. C2.

\section{Notes}

I In 1912 and 1951 union agitation occurred outside the legal framework of the Act which workers saw as offering them little protection.

2 The interpretation of the ECA by the specialist courts remained a critical aspect of the effect of the Act. The early decisions of the Employment Court and the Employment Tribunal, particularly those over the choice of bargaining representatives and lockouts, entrenched employer power. By the late ' 90 s, court decisions moved away from this position and reduced the control by employers. (Anderson, 1996). The ERA established the Employment Relations Authority

3 The case referred to is $W \& H$ Newspapers $v$ Oram [2001], 3 NZLR

4 The Herald was appealing a decision by the Employment Relations Authority that its collective employment agreement was inconsistent with the law while another Court of Appeal hearing would consider allegations of breaches of good faith bargaining (Smith, 30/1/04:4), 